\title{
Modeling the process of cost formation and their transition to the state of expenses
}

\author{
Elena Petrovna Polikarpova ${ }^{1, *}$, and Igor Efimovich Mizikovskiy ${ }^{2}$ \\ ${ }^{1}$ State Agrotechnological University Named after P.A. Kostychev, 390044 Ryazan, Russia \\ ${ }^{2}$ National Research Lobachevsky State University of Nizhny Novgorod, 603000 Nizhny Novgorod, \\ Russia
}

\begin{abstract}
Almost any activity involves a cost. From the point of view of the economy of organizations, costs are the basis of economic life. Directly or indirectly, they are the object or component of the work of all employees of an economic entity - managers, executors, service personnel, etc. In addition, their labor creates costs for the organization in view of the obligation to pay for it. In the context of digitalization of production in the agro-industrial complex, the requirements for accounting are increasing, as the main source of providing enterprise management with information on costs formation. This article studied costs as an object of accounting from the point of view of their recognition, essence, transition from one state to another. As a result of the study, on the basis of balance equality, a symbolic model of costs formation in an economic entity and a model of their transition to the state of expenses were built and substantiated. Such methods as collection and analysis of information, comparison, modeling and a balance method were used.
\end{abstract}

\section{Introduction}

Costs arise as a result of specific actions or events carried out to perform and ensure the main processes in the activity of an economic entity. However, the array of many facts of costs implementation with all the variety of resources consumed in this case in a single measure can be represented only as a result of accounting processing of primary data. It is accounting that forms information about the costs of an organization, their properties, condition, reasons for formation, movement and size. The variety and specifics of costs typical in agricultural activities [1-4] complicate the work of an accountant in the context of digitalization of production [5-9]. Therefore, it is important to study costs as an accounting object from the point of view of their classification, recognition, essence, evaluation, transition from one state to another.

The question of the relationship between costs and expenses, their similarity and identity remains controversial in research and accounting practice.

The use of these terms as synonyms, in our opinion, is associated with the long-known and customary in practice antonyms "income-expenditure", which characterize, respectively, the receipt and disposal of items, money, other property. The considered

\footnotetext{
*Corresponding author: Dikusar85@mail.ru
} 
relationship underlies the cash method of accounting for income and expenditure. Since the time of ancient civilizations, the income and expenditure form of accounting has been used. Income, expenditure and balance were registered, income and expense books were kept. Currently, one can find the use of the considered components in the accounting registers in columns "Income" and "Expenditure". An outgoing cash order is the most striking example of the modern use of a derivative from the term "expenditure" in the name of a document reflecting the disposal of an asset - cash.

However, the development of digital accounting and industrial relations led to the foundation of the principle of the isolation of property and the emergence of not only the owner's account (capital), but also the financial results account (administrator's account). These operating accounts reflect "funds that cannot be seen in nature or touched by hands, cannot be weighed or measured, as they are conditional and can only be entered through an accounting method" [10].

It is known that the financial result is formed by the ratio of income and expenditure. At the same time, the latter does not imply only the fact of disposal of assets, but is characterized by a mandatory decrease in economic benefits, which, in addition, can be in the form of an increase in liabilities. Of course, the consumption of property often leads to a decrease in economic benefits, and its final goal is to generate income. However, the formation of costs in this case is a subsequent result of the disposal of assets. The incorrect acceptance of second antonyms identical to each other in the "income-expenditure" and "gains-expenses" ratios leads to an incorrect perception of the relationship between terms "costs" and "expenses".

\section{Materials and Methods}

As a result of the collection and analysis of information from literary sources, it was established that studies of various authors prove the vicissitudes of using the terms under consideration as synonyms [11-17]. It is obvious that the study of the problem is based on the use of the earliest method of cognition - comparison. However, when comparing these accounting objects, scientists are based on an inherent characteristic of determining costs resource consumption, which implies the disposal (decrease) of the assets of an economic entity.

With regard to expenses, this implies the final disposal of an asset from an organization, for example, cash to pay for banking services [11]. It is considered that even when expenses are incurred, assets can be permanently disposed of from the organization, for example, cash when paying a supplier for materials. Here, the costs are distinguished by the target direction of drafts - the creation of an asset (materials, work in progress, finished goods, etc.). If the final disposal of an asset does not imply the formation of another asset, it is interpreted as an expense. Figure 1 illustrates the considered approach of the difference between costs and expenses in terms of asset retirement. 


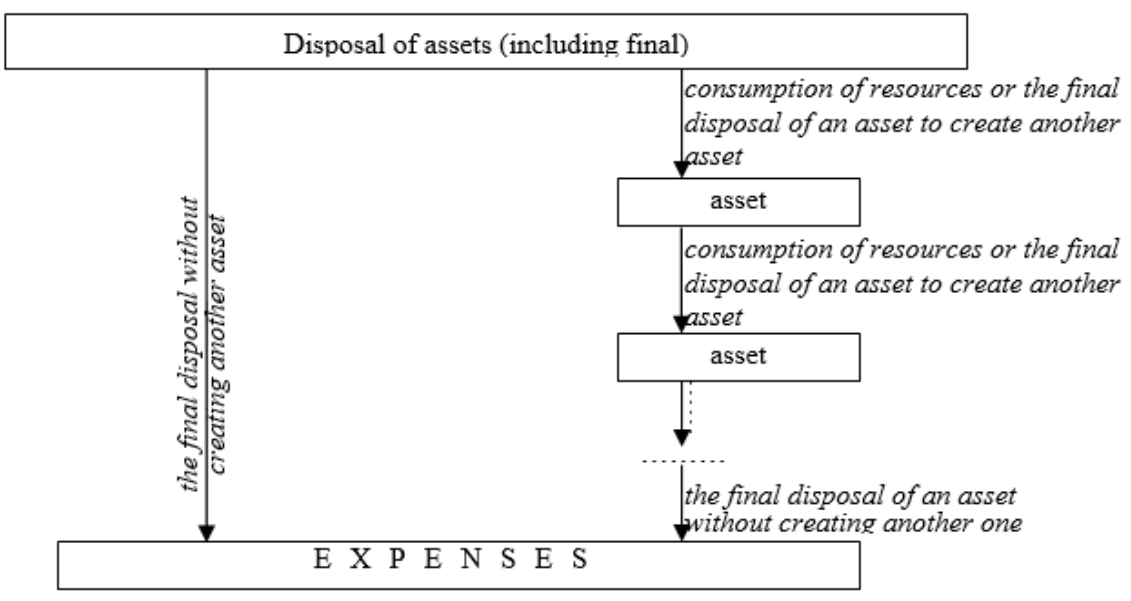

Fig. 1. Consideration of the formation of costs and expenses from the point of view of disposal of assets.

This point of view confirms that the understanding of costs is broader than the understanding of expenses. The decrease in assets as a result of the consumption of resources implies costs, if this does not involve the creation of another asset, the costs go into the state of expenses.

However, the approach under consideration requires development due to existing inconsistencies in the explanation of the formation of costs and expenses, for example:

- the final disposal of assets as an expense is the disposal of finished products (goods and other assets) upon sale. However, this disposal implies and is intended to receive cash (asset) from customers, which is expressed in the creation of an asset - a receivable, or the settlement of a liability to customers who have made an earlier prepayment involving the creation of an asset - cash;

- expenses can also be the results of an increase in liabilities, which will further require the disposal of the asset to settle them;

- the shortage of property, reimbursed by the guilty persons, implies a reduction of the asset, its final disposal, with the further formation of another asset - contributed by the guilty person, which corresponds to the interpretation of costs;

- does the cost of disposing of an asset - a receivable - generate another asset - cash (for example, when customers pay for products sold to them)?

In addition, it becomes necessary to link the disposal of assets not only with the creation of another asset, but also with a decrease or increase in liabilities.

Thus, the study of the essence of costs and expenses comes down to considering the components of the balance sheet - assets and liabilities, and changes in them, which involves the use of the balance sheet method. Balance equality here is a useful tool for modeling the process of cost formation and their transition to the state of expenses. The use of modeling, as a general scientific research method, will make it possible to form a model of the studied object for a deeper understanding of its essence.

\section{Results and Discussion}

Possible options for changing the corresponding components of the balance sheet are presented in Table 1. 
Table 1. Possible options for changes in assets or liabilities as a result of disposal (reduction) of assets.

\begin{tabular}{|c|c|c|}
\hline \multicolumn{2}{|c|}{ Options and conditions for the change } & Examples \\
\hline \multirow[t]{2}{*}{$\begin{array}{l}\text { Decrease in asset } \\
\text { (a) for (or due to) } \\
\text { increase in asset } \\
(A)\end{array}$} & $\begin{array}{l}\text { with an equivalent change } \\
\text { in assets }\end{array}$ & $\begin{array}{l}\text { Consumption of materials for the } \\
\text { production of finished products. } \\
\text { The transfer of funds as an advance } \\
\text { payment forms accounts receivable. } \\
\text { Decrease in receivables as a result of } \\
\text { receipt of previously paid goods from the } \\
\text { supplier. }\end{array}$ \\
\hline & $\begin{array}{l}\text { with different magnitudes } \\
\text { of changes }\end{array}$ & $\begin{array}{l}\text { Disposal of finished goods (or other assets) } \\
\text { for sale - an asset is created - accounts } \\
\text { receivable in a different amount }\end{array}$ \\
\hline \multirow{2}{*}{$\begin{array}{l}\text { Decrease in asset } \\
\text { (a) for (or due to) } \\
\text { reduction of } \\
\text { obligation }(o)\end{array}$} & $\begin{array}{l}\text { with a preliminary } \\
\text { increase in liability }(O) \\
\text { simultaneously with an } \\
\text { increase in asset }(A)\end{array}$ & $\begin{array}{l}\text { Payment of debts to the supplier for } \\
\text { materials purchased from him; } \\
\text { Shipment of products paid in advance to } \\
\text { the buyer; } \\
\text { Loan repayment }\end{array}$ \\
\hline & $\begin{array}{c}\text { with a preliminary } \\
\text { increase in liability }(O) \\
\text { without increasing the } \\
\text { asset }\end{array}$ & $\begin{array}{l}\text { Payment of interest on a loan, fines, } \\
\text { penalties, late fees, etc. }\end{array}$ \\
\hline \multicolumn{2}{|c|}{$\begin{array}{l}\text { Reduction of asset }(a) \text { without creating another } \\
\text { asset and without reducing liability }\end{array}$} & $\begin{array}{l}\text { Negative exchange rate difference } \\
\text { Payment to the bank for services } \\
\text { Unrecoverable losses }\end{array}$ \\
\hline
\end{tabular}

Let us express the presented options for the relationship between changes in assets and liabilities in the form of equalities and inequalities by introducing the following symbols:

$a$ is an asset decrease, rubles;

$A$ is an asset increase, rubles;

$o$ is a decrease in liabilities, rubles;

$O$ is an increase in liabilities, rubles.

The option of disposal (reduction) of an asset, as a result of which another asset is created (increased), the value of which is formed in strict accordance with the value of the asset being retired, can be expressed as:

$a=A$, or $A-a=0$.

When materials are consumed in production, the amount of work in progress costs increases exactly by their cost, as well as the value of the expected finished product in the future. When funds are transferred to the supplier in advance, the amount of accounts receivable increases by exactly their amount.

If the value of the increasing asset is formed regardless of the cost estimate of disposal, an inequality is formed:

$a \neq A$, or $A$ - $a \neq 0$, and two options are possible: $A$ - $a>0$, or $A-a<0$.

A positive result of the difference causes an increase in equity capital, and a negative result causes a decrease. In both cases, the financial result is formed in the amount of changes in equity capital, while the amount of accrued income and expenses corresponds to the amount of increase and decrease in assets, respectively.

When a finished product is sold, its cost, that is, the asset decrease, forms expenses, which does not affect the income, equal to the increase in the buyer's receivables, formed on the basis of established prices. The difference between income and expenses will form a financial result equal to the value $(A-a)$.

Thus, the considered option of asset disposal involves the formation of expenses. 
The version providing for the reduction of the asset to reduce the liability is divided into two options, depending on the conditions of the preliminary formation of the liability:

- if the liability was formed simultaneously with the increase of any asset, it is possible to form equalities:

$a-o=0$ and $A-O=0$, i.e. $(a-o)-(A-O)=0$ or $(O-o)-(A-a)=0$.

For example, when transferring funds to the supplier $(a)$ the obligation to him $(o)$, which was previously formed $(O)$ in the amount of the received goods $(A)$ is extinguished for their amount.

- if the liability was formed without increasing any asset, the following inequality is formed:

$O-(a-o) \neq 0$ or equality: $O-(a-o)=\mathrm{O}$.

The preliminary increase in the liability without creating an asset contributes to a decrease in equity, creating an expense, which subsequently causes the disposal of the asset to settle the liability. For example, the accrual of costs for servicing a loan does not imply the receipt of an asset in the organization. It forms an obligation $(O)$ to pay interest on the loan, which is later repaid $(o)$ by paying cash $(a)$.

Sometimes a decrease in an asset occurs without an increase in another asset and does not imply a decrease in liabilities. This can be expressed by the following inequality:

$a \neq 0$.

Equity capital is reduced by the amount of this decrease, and an expense is formed. An example is negative exchange rate differences that reduce the value of assets denominated in foreign currency, impairment of assets, unrecoverable shortfalls, direct transfer of funds to the bank for services under the contract, etc.

Note that the considered inequalities cause the need to reduce equity capital, thus forming expenses, which corresponds to its definition in official sources [18]. Having combined and comprehensively considered the indicated options, one can get the following equality, the failure of which can be accepted as a condition for determining expenses:

$(a-O)-(A-O)=0$.

Expenses are generated in the following cases:

$a-A \neq 0$ when disposal of an asset $(a)$, another asset $(A)$ is formed in a value independent of the cost of disposal, with $o=0$ and $O=0$;

$a-o+O \neq 0$ when disposal of an asset $(a)$, the obligation $(o)$, formed earlier $(O)$, is reduced without increasing the asset $(A=0)$;

$a \neq 0$ when the asset $(a)$ decreases, the liability does not change and another asset does not increase $(A=0, o=0, O=0)$.

In all other cases, costs are generated without providing for the accrual of costs.

However, these three versions do not preclude the implementation of costs. Each of them involves a decrease in the asset, its book value or disposal, which is an integral part of the economy of any organization. At the same time, its property is used to meet the needs of economic life.

In the second of the presented cases, expenses are generated even with the preliminary formation of the obligation, however, it is implied that the asset should be disposed of in the future. Transfer of payments for services, fines, penalties, reflection of negative exchange rate differences proceeds from the need to comply with contractual conditions, legal requirements, court decisions, which is an important factor in ensuring the activities of an economic entity.

The negative consequences of ineffective work include identification of unrecoverable shortfalls, impairment of assets and similar cases of a decrease in an asset that does not imply an increase in other assets and a change in liabilities. 
As a result of the study, a symbolic model of the formation of costs of an economic entity (1) and a model of the transition of costs to the state of expenses (2) were built and substantiated:

$$
(a-o)-(A-O)=0
$$

and

$$
(a-o)-(A-O) \neq 0
$$

where

$a$ is the asset reduction as a result of expenses, rubles;

$A$ is the increase in the asset that is the cause or result of the implementation of costs (for the creation of the asset), rubles;

$o$ is the decrease in liabilities as a result of expenses, rubles;

$O$ is the increase in the liability that is the reason for the implementation of costs (for the repayment of obligations), rubles.

The difference between the presented mathematical models in the equal (inequality) sign emphasizes the need to interpret expenses as the final state of costs.

Thus, almost any decrease in an asset, its book value or disposal, generates costs, since the reason for this is the planned or forced need to ensure the current and further work of the economic entity. In certain cases, causing a decrease in the organization's equity capital, the costs pass into the state of expenses of the period in order to maintain balance sheet equality. They can accumulate in the value of current production or financial assets, or have no preliminary accumulation (Fig. 2).

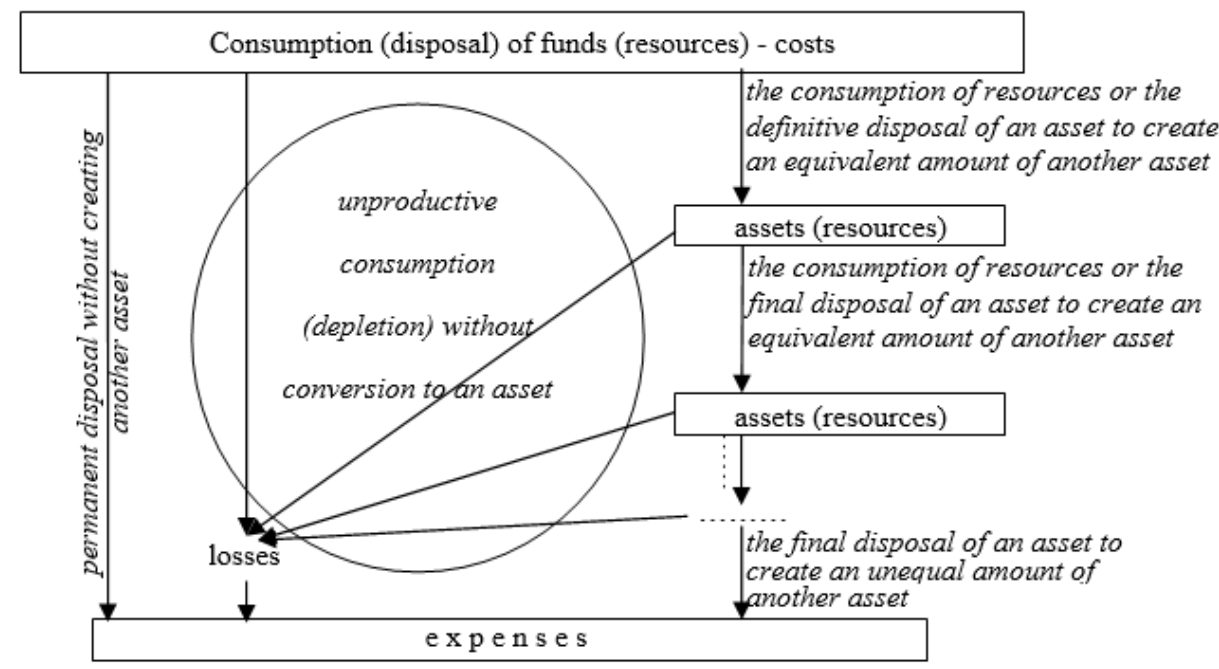

Fig. 2. Cost to expenses conversion process.

Further study of the essence of economic categories of costs and expenses implies consideration of the procedure for their recognition, for which one should go to the technical side of the issue of their accounting. The attribution of costs to ordinary or other types of activities, their accumulation in the field of supply, production or circulation, the procedure for the transition of costs to the state of expenses are implemented in the process of reflecting the corresponding business transactions in accounts. 


\section{Conclusion}

So, the basis for cost outlay is the disposal (reduction) of assets of an economic entity to ensure its current and further work. If it is not expected to increase another asset in an equivalent amount, the costs are transferred to the state of expenses. However, it is necessary to link the disposal of assets not only with the creation of another asset, but with a decrease or increase in liabilities.

As a result of the study, using balance equality, a symbolic model of the formation of costs of an economic entity and a model of the transition of costs to the state of expenses were developed and substantiated. The change in the organization's equity capital, corresponding to the developed model with an inequality sign, justified the fact of the transition of costs to the state of expenses of the period.

\section{References}

1. Z. Jiang, T. Zhou, H. Zhang, Ya. Wang, H. Cao, and G. Tian, J. of Cleaner Production, 135, 1602 (2016)

2. X. Zhao, K.V. Calvin, M.A. Wise, Climate Change Economics, 44 (2020)

3. A.S. Zavgorodnyaya, I.G. Shashkova, V.S. Konkina, L.V. Romanova, E.I. Mashkova, M.Yu Pikushina, J. of Advanced Research in Dynamical and Control Systems, 7 (Special Issue), 2022 (2018)

4. N. Dechow, J. Mouritsen, Accounting, Organizations and Society, 30, 691 (2005)

5. I.E. Mizikovskiy, E.P. Polikarpova, Bulletin for Professional Accountants, 3, 20 (2019)

6. E.P. Polikarpova, I.E. Mizikovskiy, Custos e @gronegócio on line, 14, 4, 149 (2018)

7. E.P. Polikarpova, I.E. Mizikovskiy, Custos e @gronegócio on line, 15, 4, 2 (2019)

8. G. Bakulina, G. Kalinina, I. Luchkova, M. Pikushina, A. Gracheva, BIO Web of Conferences 2019, 18 (2020)

9. Yu.N. Kudryashova, T.G. Lazareva, T.N. Makushina, and Yu.V. Chernova, BIO Web of Conferences, 17 (2020)

10. E.V. Lupikova, Historia rationem: artem (2009)

11. I.E. Mizikovskiy, L.G. Ulyasheva, State and Municipal Management Scholar Notes, 3, 206 (2016)

12. I.E. Mizikovskiy, Bulletin of the Lobachevsky University of Nizhny Novgorod. Series: Economics and Finance, 1, 201 (2004)

13. O.A. Ageeva, Vestnik universiteta, 3, 123 (2020)

14. D.A. Statkevich, Vesnik of Yanka Kupala State University of Grodno. Series 5: Economics. Sociology. Biology, 2(131), 74 (2012)

15. M.V. Manichkina, Russian Entrepreneurship, 10-2, 34 (2008)

16. O.S. Zeits, E.L. Putnikova, Bulletin of the Belarusian State Agricultural Academy, 4, 15 (2019)

17. O.S. Rostovceva, Innovative Development of the Economy, 6-2 (36), 198 (2016)

18. Conceptual Framework for Financial Reporting. IFRS ${ }^{\circledR}$ Conceptual Framework Project Summary (2018) 